\title{
The Economic Effects of Canadian - US Integration on a Border Region in the United States: Reflections from Northern New York
}

\author{
Dr. Prem Gandhi \\ SUNY Distinguished Professor Emeritus \\ Center for the Study of Canada \\ State University of New York at Plattsburgh \\ 101 Broad St, Plattsburgh, NY 12901, United States \\ Dr. Neal Duffy \\ Professor Emeritus \\ Department of Economics and Finance \\ State University of New York at Plattsburgh \\ 101 Broad St, Plattsburgh, NY 12901, United States
}

\begin{abstract}
The late 1960s saw transformational changes in economic relations between the United States and Canada. These were partly driven by the election of new leadership in both countries, and partly by the increasing political voice of Quebec within Canada. The border state of New York was uniquely positioned to experience economic consequences as successive trade agreements took hold. Yet both nations, especially Canada, first had to address long-standing economic concerns and traditions that had historically created major impediments to the concept of a more open trade and investment climate. Northern New York, in particular, found itself to be one of the chief beneficiaries, as comprehensive trade agreements were eventually passed in 1988, 1994, and 2020. This occurred despite the fact that this relatively isolated region, although very close to the United States' historical manufacturing belt, had always been considered somewhat unsuitable for economic development.
\end{abstract}

Keywords: US-Canada integration, trade policy, locational analysis, economic development, free trade, border wasteland, Northern New York

\section{Conceptual Framework}

This paper is a three-dimensional attempt to relate international trade, regional economics and locational analysis to the economic development of a single Canadian-US border region. At a macro level, we consider the effects that successive trade agreements have had on a relatively developed area, namely the State of New York. At the micro level, it examines the impact that free trade has had in altering the spatial economic chararacteristics of the relatively depressed border area of Northern New York. The paper explores these issues in the wider context of the shifts in the structure of the global economy, economic policies, and theoretical evolvements in trade and regional economic development over the past 60 years.

International trade, regional economics, and locational analysis are not typically linked together in the literature. Caves (1967) talked at length about the traditional neglect of location analysis and regional economics in any study or discussion of trade. Seymour Harris (1957) had earlier attributed this neglect to the fact that as a significant part of their economy, Great Britain elevated foreign trade to the highest level, causing it to develop, and eventually come to dominate, the modern theory of international trade. Isard (1956), on the other hand, expressed a more cynical view, attributing this neglect to "Anglo-Saxon Bias." He came to that conclusion because he felt it was somewhat irrational to believe that trade and location theory were not simply two sides of the same coin. ${ }^{1}$

In studying the economic development of a border region, one quickly comes to the realization that trade and trade policy may be two of the most critical factors involved in that development. In addition, cultural and political disparities may play a much larger role compared to other regions. It is for these reasons that regional economists have long suggested that border regions generally suffer from low economic activity, particularly manufacturing, as economic activity gravitates towards more centralized locations. The case of Northern New York exemplifies how the reduction of trade barriers, as well as an historical affinity between nations, can effectively transform a formerly undeveloped "border waste land" into a much more thriving region.

${ }^{1}$ Caves (1967). Trade and Economic Structure: Models and Methods. Cambridge: Harvard University Press. Harris (1957). International and Interregional Economics. New York: McGraw- Hill Book Co. Inc. Isard (1956). Location and Space Economy, Cambridge: The MIT Press. 


\subsection{Background: Northern New York}

The decade of the 1960swas pivotal in the social-economic-political history of Canada, and with such a close connection between the United States and Canada, it is not surprising that there were significant impacts on the border state of New York. The year 1968 may be considered a key turning point in Canada's history, and there were direct ramifications for economic development in both New York and its "North Country" subregion bordering Canada. The events that transpired in and around 1968 laid the groundwork for later policy shifts that eventually culminated in three Canadian trade agreements with the US. These became the focus of much debate, and will be discussed in detail. Of special interest is the fact that the flourishing of trade proved to be a significant stimulus to the North Country. This was somewhat surprising to local leaders because this region, although very close to the United States' historical manufacturing belt, had always been considered unsuitable for economic development. We therefore begin with a brief description of the region, followed by an extensive discussion of Canadian economic history focused on trade. Finally we examine the effects on the regional growth of New York State, as well as its North Country area that borders Canada.

Northern New York covers one-fifth of New York State and comprises six counties: Clinton, Essex, Franklin, Jefferson, Lewis, and St. Lawrence. The region has sometimes been described as an 'agropolis,' a rural-urban region possessing a dual economy. In the 1950s the two largest cities were Plattsburgh in the East, and Watertown in the West (populations 15-20,000); both cities were considered to be regional centers, while the rest of the area was agricultural and forested. Much of the population increase since the 1950s was directly attributed to government activities having to do with the growth of several state colleges, the construction of two international bridges plus the St. Lawrence Seaway, and the expansion of military installations at Plattsburgh and Watertown. But up to the middle of the twentieth century Northern New York was a place perceived to be economically isolated. It had lower income and literacy rates, a concentration of seasonal activities, a large public sector, and a shortage of skilled labor. Table 1 summarizes some of the relevant characteristics regarding labor and demographics for the state, the Northern NY region, and its six counties. But as we will see, the latter half of the twentieth century presents an interesting case study of the economic development of a relatively isolated region in one country (the US), located in the shadow of two much more prosperous regions in another country (Ontario and Quebec provinces in Canada).

Table 1

Socio-Economic Profile of Northern New York in the 1960's

$\begin{array}{lllllllll} & \begin{array}{l}\text { NY } \\ \text { State }\end{array} & \begin{array}{l}\text { Northern } \\ \text { NY }\end{array} & \text { Clinton } & \text { Essex } & \text { Franklin } & \text { Jefferson } & \text { Lewis } & \begin{array}{l}\text { St. } \\ \text { Lawrence }\end{array} \\ \text { Area (sq. mi.) } & 47939 & 9923 & 1059 & 1826 & 1685 & 1293 & 1293 & 2767 \\ \text { Population (000's) } & 16782 & 375 & 73 & 35 & 45 & 88 & 23 & 111 \\ \text { Pop \%ch. 50's } & 13.1 & 10.1 & 35.6 & 0.6 & -0.1 & 2.7 & 3.2 & 12.4 \\ \text { \% Urban } & 85.0 & 38.0 & 34.4 & 23.6 & 41.5 & 42.7 & 15.6 & 44.4 \\ & 86.7 & 80.6 & 85.6 & 92.0 & 72.6 & 79.7 & 69.2 & 77.3 \\ \text { Net migration } & 1.4 & -5.6 & 15.6 & -11.2 & -12.6 & -8.6 & -12.5 & -4.2 \\ \text { \% in labor force } & 56.5 & 52.0 & 52.0 & 52.0 & 52.4 & 54.2 & 54.9 & 49.6 \\ \text { \% Unempl. } & 5.2 & 10.4 & 10.1 & 10.5 & 14.6 & 8.4 & 6.2 & 11.5 \\ \text { \% Empl. by gov't } & 11.7 & 16.4 & 21.7 & 14.9 & 17.4 & 13.0 & 16.0 & 16.7 \\ \text { Wage rate (hr.) } & 2.54 & 2.57 & 2.36 & 2.57 & 1.61 & 2.50 & 2.26 & 3.03 \\ \text { Sources } & & & & & & & & \end{array}$

Sources

(1) NY Department of Commerce, Business Fact Book, 1963: Northern Area, Part 2, Population and Housing (Albany, NY: 1967-68). (2) Business Fact Book, Part 1, Business and Manufacturing (Albany, NY: 1967-68). (3) US Bureau of the Census, County and City Data Book (Washington, DC: Government Printing Office: 1967). 
In the 1950s, regional economists had begun investigating the possible effects of borders in pushing or pulling away investment, especially in manufacturing. E.M. Hoover described political boundaries as a form of trade barrier, and surmised that such locations were therefore relatively disadvantageous as processing centers. ${ }^{2}$ Such locations were often described as "border wastelands." But in the case of Northern New York there were other physical barriers. In addition to the Canadian border, these included the Adirondack Mountains and wildernessto the South and West, the St. Lawrence river to the Northwest, and Lake Champlain to the East. Although it was not very far from major US metropolitan areas such as Boston and New York, and was less than half a day's drive from the US manufacturing belt, it had always been perceived as being somewhat removed from those more thriving areas.

In many ways the North Country is not a difficult place to understand, from either the historical or economic perspective. As a so-called border wasteland with various geographical disadvantages, it evolved towards having a resource- and government-based economy and relatively few exports. However, another significant disadvantage was political. Its population averaged only about $1 \%$ of a state dominated by a major international economic center (New York City),located just 300 miles to the South. While the state of New York is about $7 \%$ of the total population of the US, the North Country itself never achieved the critical mass necessary for the cumulative processes of growth to take hold.

By contrast, the Canadian provinces of Ontario and Quebec, both of which border the North Country, comprise about 60\% of Canada's population and GDP, and represent the very heart of Canada's political/economic structure. In many ways the evolution of the North Country cannot be fully understood apart from its linkage to Canada, both of which are subsumed under the more general history of Canadian-US relations. This will require us in this paper to go into considerable detail on some of the complexities of Canadian economic development and its historical relationship with the US. We will therefore need to examine some of the important social and political events arising in Canada that had such widespread influence in both countries, but especially the North Country.

\subsection{Canada}

The 1960s was a decade marked by major economic, political and societal changes emanating to a large extent from the French-Canadian-population of Quebec. In the first century after Canada became a federation in 1867, many French-Canadians had felt like outsiders compared to the rest of English-speaking Canada, a sense beautifully captured in the novel Two Solitudes. They had little control over the enormous resources that were largely controlled by English-speaking Canadians. French-Canadian life was dominated by the Church and the traditional professions; few were drawn into business, engineering, science or other technical fields. A break in this pattern came in the early 1960s as the province of Quebec experienced what would later be dubbed "the Quiet Revolution."This was a period in which French Canadians felt a renewed self-confidence that arose in part from the emergence of Quebec out of the stifling influence of church-dominated values and traditions. As a result, there began a slow movement away from traditional occupations to modern fields in business, medicine, and technology.

Among various centennial celebrations in Canada, Montreal inaugurated Expo67 to showcase the many achievements since the landing of European settlers. As a part of the year-long celebration, countries around the world and many foreign dignitaries were invited to participate. The President of France, Charles de Gaulle, was accorded special prominence because of France's historically close ties to Canada, and because of the dominance of the French-speaking population in Quebec. During his visit, de Gaulle spoke of Quebec and the special cultural bondit had with France. Many French-speaking Quebecers had historically felt like outsiders compared to the rest of English-speaking Canada, but he assuaged them with talk of "vive le Quebec libre," which later became the rallying cry of Quebec separatists. The formation of Parti Quebecois in 1968, under the leadership of Rene Levesque, soon formed an influential political base.

\section{Economic Relations between the US and Canada}

In 1959 a watershed event occurred at the Canada-New York border -the opening of the St. Lawrence Seaway. Officials from both Canada and the Northern US were suddenly focusing on their common culture and history, and how the Seaway would strengthen economic relations. The Seaway was portrayed as a "third coast" that would serve to integrate New York and Canada with Europe and beyond. But at the same time there emerged a rise in economic nationalism throughout Canada that would not only conflict with Quebec's rising separatism, but would also threaten Canada's historically warm relations with its Southern neighbor. The state of New York, and in particular its Northern-most region, was integrally involved owing to its proximity to the center of controversy, Quebec.

\footnotetext{
${ }^{2}$ Hoover (1963). The Location of Economic Activity, New York: McGraw-Hill Book company, Inc. Paperback, p. 222.
} 
The manufacturing belt in the United States is 1000 miles long and 350 miles wide, stretching from Boston and New York City in the East, to Chicago in the mid-West. Not that far to the north, Canada mirrors that (East-West) distribution, with three-quarters of its economic activity concentrated in just Ontario and Quebec. The Canadian industrial belt extends from the cities of Quebec and Montreal (Quebec) in the East, to Ottawa and Toronto (Ontario) in the mid-West. Regional economists had shown that outlying regions located in proximity to economic hubs frequently benefited by attracting industry and investment. ${ }^{3}$ It was therefore potentially significant that Northern New York was closer to the major Canadian axis of economic activity than to the US axis. Yet, apart from legal restrictions, there remained at least three historical impediments to trade and economic integration: the international border, the St. Lawrence river, and to some extent a language difference with French Quebec.

Northern New York benefited directly from the spillover effects of Expo67. The celebrations in Montreal and other locations throughout Canada attracted American tourists who traveled on the newly constructed Interstate Highway 87 (The Northway) through the North Country on their way to Canadian Highway 15, and the province of Quebec. They could appreciate an area of beauty that previously might have been limited to few visitors. ${ }^{4}$ In addition, the opening of the Northway in 1967 immediately connected the North Country more closely to large markets in both the South (New York, New Jersey, etc.) and the North (Montreal).As one of the important centers of the North Country, Plattsburgh, located only 20 miles from the border and 60 miles from Montreal, found itself in the middle of many of the debates over a whole series of economic-trade-development issues emerging between the two countries.

Prior to this there had been both hot and cold phases to the long history of trade between Canada and the US. AReciprocity Agreement was enacted in 1854 that abandoned tariffs on resource imports from Canada that had stood at nearly21 percent. High tariffs then returned when the treaty was unilaterally abrogated by the US in 1866 . With the 1879 National Policy Act, Canada again instituted more protectionist policies aimed at advancing its manufacturing sector. After that, there were sporadic attempts to reduce trade barriers until 1911, when Canada elected a conservative government firmly opposed to free trade. The favorite slogan became "no truck or trade with the yankees."'It was not until the Auto Agreement of 1964 that initial attempts were made to integrate firms in similar industries across the border. The success of this endeavor subsequently led to the consideration of even wider reductions in trade barriers and tariffs.

The structure of trade and the Canadian economy that existed in the 1960's could be summarized as follows:

1. The majority of Canadian economic activity was concentrated in just two provinces, Quebec and Ontario, both sharing a border with the state of New York.

2. In 1965,trade with the US stood at $\$ 11$.0billion,with the US accounting for 58 percent of Canadian exports and 70 percent of Canada's imports. Canada's total trade was 33 percent of its GDP; for the US it was only 6 percent. $^{5}$

3. Canada's exports were mostly resource-based: forestry products, natural gas and petroleum, with the major exception being automobiles (and parts). US exports to Canada consisted of machinery, electrical equipment, chemicals, fresh fruits and vegetables, and automobiles (and parts).

4. As a result of such a structure, Canada experienced trade deficits with the US. But although it had a $\$ 1.1$ billion deficit with the US in 1965 , over $\$ .60$ billion returned in the form of long- term investments. As a result, by that time the US accounted for almost 85 percent of the $\$ 30$ billion foreign ownership of Canada. However, in the 1960s Canada was yearly investing twice as much in the US as the US was in Canada, per capita. ${ }^{6}$

5. Capital imports (investment) from the US went into the ownership of strategic sectors like manufacturing, petroleum and natural gas, mining and smelting, railways, and other utilities. And, except for railways and other utilities, that ownership tended to increase:

${ }^{3} \mathrm{P}$. Gandhi studied 467 counties in the US and Canada, concluding that the distance to metropolitan areas was an important contributor to economic growth in adjacent regions (unpublished dissertation, The New School for Social Research, 1973).

${ }^{4}$ The Adirondack mountain area is considered to be both a sportsman's paradise and a prime destination for those with health concerns seeking a cleaner, healthier environment.

${ }^{5} \mathrm{GDP}$ is used merely as a reference; by definition imports are not included in national production.

${ }^{6}$ (Canadian investment in the US / Canadian population) was twice the ratio of (US investment in Canada / US population) on a yearly basis (flow). See Brecher (1965), Capital Flows Between Canada and the United States. Montreal: Private Planning Association of Canada, p. 5. 
From 1957 to 1963 it went from37to 44 percent in manufacturing and from 54 to 57 percent in petroleum and gas; mining and smelting remained at 47 percent. Within the automobile (and parts) industry,US control was almost total. $^{7}$

Then in 1968 Canada elected a French-Canadian to be its new Prime Minister. Pierre Trudeau was greeted enthusiastically in many quarters, promising a fresh perspective to resolving one of the main issues: Quebec's demand for national sovereignty. Educated in the European liberal and socialist tradition, Mr. Trudeau was a charismatic leader who sought to elevate the status of Canada at the world table. He brought with him a strong nationalist vision that dominated Canadian politics until he left office in1984. But he was immediately faced with the repercussions of Quebec's increasing sectionalism. In 1968-69, Quebec faced a series of robberies and bombings that unsettled Canadians and Quebecers, especially those that had fled Europe during WW 1l. These were people who had lost everything during the war and had settled into a new life in Canada. The demonstrations brought back enough traumatic memories that many were crossing into Northern New York to bring precious belongings for safe-keeping. Then in October 1970the Front de Liberation du Quebec kidnapped two government officials (the deputy Prime Minister of Quebec and a British diplomat), igniting a major political crisis that escalated when one of them was later killed.

\section{Impediments to Integration}

The increasing sectionalism centered in Quebec came at a very inopportune time. Economists had already begun to promote the idea that free trade would not only make Canadian industries more competitive, it would serve nationalistic purposes as well. But Canada's fear of broader integration with the US had a solid basis having to do with the composition of trade. While both countries exchanged resources, to Canada they represented two-thirds of her exports to the US, and were duty-free. Because she enjoyed such a tremendous comparative advantage in resources, it was therefore felt that Canada would not receive very much benefit from "freer" trade. Most US exports, on the other hand, consisted of manufactured goods that were capital and technology-intensive. These products were exported to Canada at heavy duties in order to protect Canada's domestic industry. Canadian prices relative to the US were already higher in the 1960's due to the small size of Canadian firms and the lack of competition. And with such high tariffs, Canadian manufacturing had little incentive to improve efficiency and cut prices.

In Canada's view, closer integration with the US would primarily benefit United States exporters, potentially reducing Canada to merely "hewers of wood and drawers of water." Long ago this fear was at the heart of Canada's protectionist National Policy that was developed back in the 1870s. It wasn't until the Kennedy Round of tariff negotiations in the 1960s that there were attempts to reduce tariff barriers (among many other nations as well) that had existed for so long. Economists made predictions that both Canada and the US might eventually see average duty rates (ad valorum) fall substantially by the year $1972 .{ }^{8}$ Many Canadians viewed those projections with favor, considering this more all-inclusive approach to be a "second option" to a single bilateral agreement with the US.

Another concern over integration was the possible negative effect on the inflow of foreign investment from the United States. Tariffs on imports into Canada had always made it attractive for US firms to produce in Canada. Data provided by the Dominion Bureau of Statistics revealed that in 1963 non-resident control of Canada's manufacturing sector was a very large (by world standards) 60 percent, with the US controlling 40 percent. However, 95 percent of the automobile industry, 80 percent of the chemical industry, 74 percent of petroleum and natural gas, 59 percent of mining and smelting, and 43 percent of paper and pulp, were owned or controlled from abroad, mainly by the US. ${ }^{9}$ A 1967 estimate by Tupper and Bailey showed that 45 percent of Canada's GNP stemmed from US investment in 6000 companies owned or controlled by the US. ${ }^{10}$

Whatever the reasons for the seemingly excessive amount of foreign investment, the structure of Canadian companies and the economy seemed well-established. Foreign-owned Canadian companies all faced the same problems: (1) a small market spread over a large area, leading to (2)a number of built-in inefficiencies, resulting in (3) prices that were too high for world markets.

In1957 a study by the Royal Commission on Canada's Economic Prospects pointed out that "This is notably true of secondary manufacturing in Canada, where productivity would seem to be from 35 per cent to 40 per cent lower on

\footnotetext{
${ }^{7}$ Ibid.

${ }^{8}$ This is a general statement in that once nations embark on a reduction of trade barriers they would theoretically observe the mutual improvement in trade and welfare, and therefore become more amenable to even lower tariffs.

${ }^{9}$ Dominion Bureau of Statistics (1967). The Canadian Balance of International Payments and International Investment Position, 1963, 1964, 1965. Ottawa: Queens Printers.

${ }^{10}$ Tupper and Bailey (1967). Canada and the United States: the Second Hundred Years. New York: Hawthorn Books, Inc., p. 99.
} 
the average than in the United States." ${ }^{11}$ Economists labeled Canada as a small replica of the United States because it produced similar products, but at a lower level of productivity. As a result, Canada's per capita income was only about 70 per cent of that of the US.

In an attempt to limit foreign and promote domestic investment, Canada established the Canada Development Corporation (CDC) in 1971 and the Foreign Investment Review Agency (FIRA) in 1973. The intent of the CDC was to promote Canadian investments in Canada, while FIRA was set up as a watchdog agency that screened foreign capital on the basis of whether it contributed substantively to job creation. These policies were highly criticized by US President Richard Nixon, and to protect American interests he attempted to reciprocate. Although Canada had traditionally enjoyed 'exempt' status from any (generally) adverse US economic policies, it found that it would no longer qualify. Tariffs we rescheduled to be raised on all imports to the US, including those from Canada, in order to address a trade deficit that had been mushrooming since the 1960s. These sanctions, though later lifted after Canada's protestations, were imposed at a time when both countries were facing a period of stagflation resulting from the OPEC energy crisis of the mid-70s.In response to that crisis, Petro-Canada (a Crown Corporation) was created in 1975 as the centerpiece of a Canadian program to regulate prices and secure Canadian ownership of domestic oil and gas.

Despite these temporary setbacks, some Canadian and US businesses, particularly in the auto industry, strived to integrate supply-chains to better serve both markets. This was partly a response to academic studies that had measured (and forecasted) the adverse welfare implications of trade restrictions. Young had found that Canadian tariffs raised consumer prices by as much as 4.5 percent of Canadian GNP every year. ${ }^{12}$ The Wonnacotts later estimated that US import tariffs were even more burdensome, costing Canadaan additional 6 percent, potentially bringing the total cost up to as much as 10.5 percent of GNP. ${ }^{13}$

In short, right up until the signing of the first trade agreement in 1988, all of the analyses suggested that Canada was facing three problems related to its economic development and its relationship with the United States: (1) a lop-sided pattern of trade featuring heavy dependence on resource-based and semi-processed exports, (2) importation of manufactured products that had a heavy capital and technology content, and (3) a heavy concentration of US investment that was resulting in the outside control of strategic industries.

\section{Trade Awakening: Setting the Foundation}

Though Canadians had traditionally been fearful of integration, they began to realize that trade impediments were more than likely contributing to its comparatively low per-capita income. Many were persuaded that relaxation of certain barriers would a) pave the way for Canadian access to the vast US market,b) facilitate improved productivity of Canadian business,c) raise Canadian incomes, and d) lower the prices of US products sold in Canada. Precedents had been set by the success of the European Common Market, which had been in existence since 1957. But due to concerns over the loss of national sovereignty, the models being discussed tended to be in favor of a far looser type of integration.

In the political arena Mr. Trudeau was having to contend not only with domestic turbulence, but foreign (i.e. US) as well. Within his (nearly) 16 year tenure, the US would have four presidents, but at the beginning of his term Richard Nixon was the one who viewed him, and Canada's overall agenda, with the most suspicion. His relations with Mr. Nixon and his right hand man, Henry Kissinger, were anything but warm. They viewed Mr. Trudeau's political overtures to Cuba and China, and his sharp criticism of US militaristic policies in Vietnam, with a strong degree of contempt. Meanwhile, Quebec separatism, US dominance of the Canadian economy, and the war in Vietnam were inciting loud demonstrations all over Canada.

These factors, both political and economic, led substantial numbers of Canadians to become increasingly nationalistic, with stronger US relations widely considered to be only a second or third best option. Many leaders were in favor of multi- rather than bi-lateral tariff reductions, with one proposal being the formation of an Atlantic Free Trade Association (AFTA). ${ }^{14}$ Yet at the professional level some academics were viewing free trade in more favorable terms. Canadian economists Paul and Ronald Wonnacott analyzed the impact of free trade on 16 industries in 18 regions and concluded that Canada would in fact be competitive in several areas. ${ }^{15}$ This contradicted the popular wisdom, which held that many industries would be likely to exit Canada and move right across the border.

\footnotetext{
${ }^{11}$ Royal Commission on Canada's Economic Prospects: Final Report (November 1957), Ottawa, p. 48.

${ }^{12}$ Young (1957). Canadian Commercial Policy, Ottawa: Royal Commission on Canada's Economic Prospects.

${ }^{13}$ Wonnacott and Wonnacott (1967), Free Trade Between the United States and Canada. Harvard University Press, Cambridge, Massachusetts.

${ }^{14}$ The AFTA was to include Canada, the US, the European Common Market and European Free Trade Association, and Japan.

${ }^{15}$ Wonnacott and Wonnacott (1967), op. cit. 
They believed, however, that there were particularly significant agglomeration economies in the Montreal-TorontoWindsor axis that would position it well for the North American market. But before addressing such economic matters Canada needed to reconcile the growing controversy between federalism and Quebec sovereignty.

The former issue was not addressed until late in Trudeau's administration when Canada patriated all British legislative and constitutional powers specified in various British-North America Acts dating from 1867; by 1982 it put into place a new constitution. The more difficult issue of Quebec sovereignty had been an ongoing theme since at least 1963. Under the leadership of Rene Levesque and the Party Quebecois, a number of steps were taken to strengthen Quebec's place in Canada, including a new emphasis on French language and culture. In 1969 the Official Languages Act effectively made Canada both bicultural and bilingual. Within Quebec, Bill 101 (1977) required French to be the provincial medium of communication for both its government and its media. However, it was perceived as being somewhat hostile to business, and many Canadian international corporations previously located in Montreal ended up fleeing to English-speaking Toronto. As a result, Toronto became Canada's new business and financial capital, transforming itself into a major cosmopolitan city in the process.

By 1984, as the Trudeau era was coming to a close, it became clear that it had indeed been a pivotal time in the modern economic history of Canada. With the establishment of FIRA and CDC, the goal of limiting the growth of US investment was attained, while at the same time the investment position of Canada in the US significantly increased. By the late 1980's studies showed that Canadians controlled 1,773 companies in the US, employing 600,000 , with a wage bill of $\$ 16$ billion. ${ }^{16}$ Researchers estimated that US investment stock in Canada stood at 8 times the value of Canadian investment stock in the US. ${ }^{17}$ But by the mid-2010s, the situation had reversed: Canadian investment stock in the US suddenly stood at 1.6 times greater than US investment in Canada (Table 2). ${ }^{18}$

Of equal importance to the Trudeau legacy were academic initiatives that reviewed the question of greater integration with the US. A final report by the Royal Commission on the Economic Union And Development Prospects for Canada came out just after he left office, but the groundwork had been laid. Recommendations for freer trade led to Canada's so-called "leap of faith," culminating in the passage of two major trade agreements in 1988 and 1994.

Table 2

Canada-US Trade and Investment, 2006-2017 (\$billions, US)

$\begin{array}{llllllll} & \underline{2006} & \underline{2008} & \underline{2010} & \underline{2012} & \underline{2014} & \underline{2016} & \underline{2017} \\ \text { US Exports to Canada } & 231 & 261 & 249 & 293 & 313 & 267 & 282 \\ \text { US Imports from Canada } & 302 & 339 & 278 & 324 & 349 & 278 & 299 \\ \text { NY Exports to Canada } & 16.4 & 18.6 & 16.9 & 18 & 20.1 & 18 & 12.6 \\ \text { NY Imports from Canada } & & 30.5 & 24.0 & 22.0 & 23.9 & 21.0 & 29.3 \\ \text { US FDI stock in Canada } & 251 & 247 & 330 & 367 & 370 & 365 & 391 \\ \text { Canada FDI stock in US } & 170 & 194 & 225 & 246 & 328 & 458 & 524 \\ \text { US FDI in Canada (annual) } & 15.6 & 12.3 & 17.6 & 29.6 & 30.6 & 13.8 & 18.6 \\ \text { Canada FDI in US (annual) } & 14.8 & 16.8 & 7.4 & 17.3 & 23.5 & 67.1 & 71.9 \\ \begin{array}{l}\text { Empl in Canadian Co. in US } \\ \text { (000's) }\end{array} & & 411 & 399 & 409 & 448 & 474 & \\ \text { Empl in Canadian Co. in NY } & & 37.4 & 35 & 35.7 & 49.5 & 51.3 & \end{array}$

\section{Sources}

(1) US Census Bureau, Foreign Trade Administration: Trade in Goods and Services (1985-2018)

(2) US Department of Commerce, US Foreign Direct Investment, Position and Flow (select years)

(3) US Census Bureau, International Trade Administration, Foreign Trade Division

\footnotetext{
${ }^{16}$ McGahey and Doh (1991). Effects of Freer Trade on New York State: Economic Impact and Policy Considerations, Chapter 8; in Economic Opportunities in Freer U.S. Trade with Canada, Frederic C. Menz and Sarah A. Stevens (eds.), State University of New York Press, Albany, NY.

${ }^{17}$ Rugman (1987). Outward Bound: Canadian Direct Investment in the United States. Toronto: C.D. Howe Institute.

${ }^{18}$ Statistics Canada, International Investment Position, Canadian Direct Investment Abroad and Foreign Direct Investment in Canada, by Country, 2018, Table 36-10-0008-01.
} 


\section{Effects on the Border Area}

The October Crisis of 1970 was closely watched in Plattsburgh and surrounding communities. It was widely covered in local newspapers, since many area residents had familial relations with Montreal and its periphery. Many banks in Northern New York found themselves inundated with capital transfers from Quebec residents into local safety-deposit accounts. This came at a time when the North Country was experiencing other turmoil related to national and international events. Having four State University of New York (SUNY) colleges, two private universities and two military bases, there were many campus demonstrations against the US-led war in Vietnam. Plattsburgh, in particular, was home to both a SUNY campus and a large strategic Air Force Base. Moreover there were indications that many airstrikes in Vietnam were carried out by personnel stationed there. Of course the plethora of veterans residing in the area viewed the on-going demonstrations with contempt, and had no sympathy for the protesters. The assassinations of Dr. Martin Luther King Jr. and presidential candidate Robert Kennedy in 1968 added fuel to the fire. However, if there was a silver lining, it was that a subtle cultural shift had begun to take place - with all of these national and international events swirling around so close to home, local residents no longer perceived themselves to be quite so isolated.

In the presence of such a turbulent state of affairs, economic integration was being looked at as something of an antidote. The provinces of Ontario and Quebec were the heartland of Canada's manufacturing base, and had been predicted to be the most affected by any trade agreement. And fortunately for the border area, residents of both provinces were arguably more familiar with Northern New York than were even residents of New York City. But in the 1960's and 1970's not many goods originating in the North Country were exported to Canada, nor were many Canadian goods imported to the region. The two major entry points of Lacolle-Champlain in the East and MassenaCornwall in the West were simply conduits of trade between Canada and the rest of the United States. Yet the eastern part of the region, notably Plattsburgh, had substantial social-historical connections with Quebec dating back a couple hundred years, readily seen in the prevalence of local French surnames. With transportation improvements, Northern New York found it advantageous to begin marketing itself as an attractive destination for shopping, sports (1980 Winter Olympics), hiking, sailing, skiing, etc. The advent of local shopping malls accelerated the influx of visitors. Soon Canadian tourists were accounting for as much as 33 percent of retail activity in Clinton County. ${ }^{19}$

The impact of Canada on Northern New York was not limited to just tourism and trade. The state of New York was very much involved in attracting Canadian investment, and had established a liaison office in nearby Montreal. A 1965 publication of the State Department of Commerce concluded that many Canadian firms had established plants there in order to avoid tariffs. ${ }^{20}$ Many of those companies subsequently saw their sales rise to such a degree that they experienced problems in serving American customers from distant Canada. Ironically, even though American companies had traditionally thought of Northern New York as being too isolated, Canadian companies were suddenly finding it increasingly attractive as a base from which to serve their growing US markets.

In 1971, Gandhi investigated the possible factors responsible for Canadian firms locating in Northern New York's Clinton County (and Plattsburgh). ${ }^{21}$ Seventeen firms that started operating between 1963 and 1969 were surveyed, all but one of which were from Canada. ${ }^{22}$ The study asked three questions: (1) What were the reasons for locating in the area?(2) What were the problems encountered after establishment?(3) What were their reactions to proposals for free trade? In contrast to the aforementioned study, he found that tariffs were not even among the top 10 reasons cited. Instead, the three most important advantages to a Clinton County choice of location were (1) proximity to the Montreal metropolitan area, (2) labor costs, and (3) customer service. None of the reasons usually promoted by regional leaders -natural beauty, low cost of energy, tax incentives, government support, or banking, were even mentioned. Those results were confirmed by later, similar studies (Table 3).

To some extent the movement of Canadian investment in the 1960's and 70's was precipitated by domestic conditions in Canada. The militancy of Parti Quebecois, the passage of Bill 101 and FIRA, and the frequent disruptions in essential services due to protests and strikes throughout the period, contributed to an increased level of uncertainty and red-tape. The strength of labor unions and their demands for higher wages unmatched with higher productivity also made the cost of production that much more expensive. Strikes involving the Canadian

\footnotetext{
${ }^{19}$ In the case of Plattsburgh it was not uncommon to see as many as 100,000 Canadian visitors during the summer taking advantage of the area's natural attractions. See Csipak (1992) Retailing South of the Border: the Case of Quebec Shoppers in Plattsburgh, New York. The Canada-US Economic Relationship. Focus Canada Series. Center for the Study of Canada, Plattsburgh, NY.

${ }^{20}$ New York State Department of Commerce (1965). Business in New York State: An Interview, Canada Businessmen Tell Why They Established a Branch Plant in New York State. Albany, NY, November-December.

${ }^{21}$ Gandhi (1971). Canadian Investment in Clinton County: Some Empirical Observations on Location. Papers on the Social Sciences, Number 4, Canadian Studies Issue. State University of New York at Plattsburgh, 33-44.

${ }^{22}$ The only non-Canadian company was a major paper producer which had a significant trade relationship with Canada. 
postal service were particularly devastating, contributing to supply-chain impediments among small- and mediumsize firms. ${ }^{23}$ It was therefore not surprising that many companies began to look more favorably on developing support facilities in nearby New York. The linkage of Canadian Route 15 with US Route 87also made it much easier for company executives to commute back and forth between New York and Montreal.

Table 3*

Reasons for Location in Northern NY: Consistency of Previous Studies

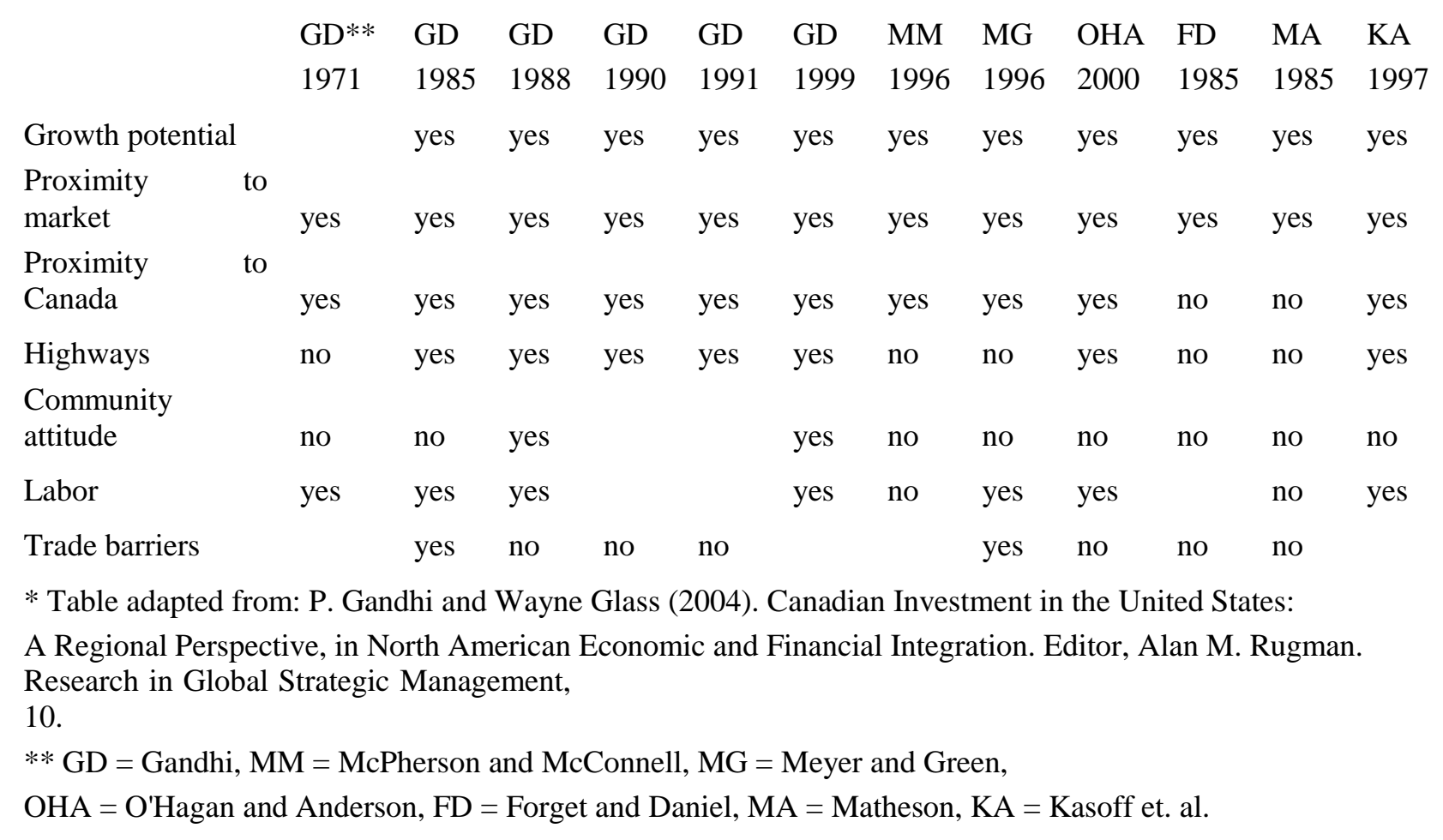

\section{The Rise of Free Trade}

Canada had begun negotiating for a free trade agreement with the US during the last years of Trudeau's administration. Significant opposition arose from Ontario, but Quebec surprised most observers by strongly supporting it because it was viewed as a counter to English Canada. There was also a strong desire to buy cheaper products from the US rather than the costlier products from Ontario that came about partly from the passing of the New Economic Policy of 1979.

Whatever the reasons for and against, the Canada-US Free Trade Agreement (CUSFTA) became a reality in 1988 and took effect in 1989, giving Canada greater access to a US market that was 10 times as large as its own. Though it stipulated that tariffs were to be eliminated over a period of 10 years, the elimination of many non-tariff barriers were considered to be quite important as well. Additional provisions protected cultural activities ${ }^{24}$ and established a mechanism to resolve future disputes. However, while government officials were celebrating the agreement, both countries were confronted with several challenges, including a world-wide recession brought about by the Asian financial crisis. Tight monetary policy was accompanied by persistently high interest rates throughout the period, and in the US tax cuts and an expansionary fiscal policy had brought about very large federal deficits. To make matters worse, newly-elected president George H.W. Bush called for "no new taxes," thus making sensible fiscal policies even more unlikely.

It was not unexpected that Canada's problems would turn out to be more severe than in the US.In some industries the agreement would require a significant amount of restructuring, at a time when labor unions wereunder increasing pressure due to high unemployment. More dramatic were the policies instituted to try and control inflation and a growing federal deficit.

To this end a seven percent national GST (goods and services tax) was implemented, with additional provincial taxes bringing the total GST to 11-15 percent for the largest provinces. But the coordinated efforts of monetary and

\footnotetext{
${ }^{23}$ Since 1965 there were 19 major disputes involving the Canadian Union of Postal Workers

(thecanadianencyclopedia.ca/en/article/cupw-postal-strikes).

${ }^{24}$ The purpose of which was to maintainCanadian sovereignty over the media and the arts.
} 
fiscal policy eventually brought inflation down to only two percent, and a national budget surplus was finally achieved as Canada entered the $21^{\text {st }}$ century. On the political front, Canada had failed to approve the proposed Meech Lake Accord that would have accommodated Quebec's growing demand for greater sovereignty. This meant that the ongoing clash between nationalists and separatists was at least temporarily abated.

Despite its initial concerns, and some painstaking adjustments, CUSFTA was considered to be a success. But no sooner did Canada adjust to freer trade, than it faced its next crisis when the US began negotiating with Mexico for a separate trade agreement. Canada had very little trade with Mexico at the time, but its relative advantage with the US in some industries happened to be similar to Mexico's advantage relative to the US. It was feared that if a separate trade agreement were to be signed without Canada's involvement, Canada could lose out to both countries because of Mexico's less stringent (and therefore less costly) labor and environmental regulations. ${ }^{25}$ Such considerations led Canada to ask to be a party to new trade discussions, and this led to the signing of a comprehensive North American Free Trade Agreement (NAFTA) in 1994 involving all three nations. ${ }^{26}$

The greater degree of integration that resulted between the US and Canada is seen by the fact that by 2001 bilateral trade reached $\$ 361$ billion, with70 percent accounted for by intra-firm exchanges. ${ }^{27}$ By the end of the first decade of the $21^{\text {st }}$ century two-way trade had reached $\$ 551$ billion and there were significant increases in cross-border investment as well. From 2001 to 2010 United States direct investment in Canada went from $\$ 153$ to $\$ 319$ billion, and Canada's investment in the US went from $\$ 92.4$ to $\$ 211$ billion. This is what led to the considerably greater ownership of net capital stock in the US by Canadians that we see today (cited earlier).

\section{Economic Effects on New York State and the Border Area}

The US as a whole did not expect much benefit from CUSFTA, but that was not true for individual states. As the largest state to border Canada, New York was indeed well-positioned. In the first year of the agreement, New York's exports to Canada quickly rose from $\$ 3.8$ billion in 1988 to $\$ 5.5$ billion in 1989 , with 90 percent going to neighbors Ontario and Quebec. Fifty-four percent of these were high value-added, technology-intensive products such as industrial machinery; equipment related to computers, transportation, and electronics; instruments and related products; and chemicals and allied products. However, in 1989 New York imported $\$ 12.2$ billion from Canada, resulting in a trade deficit that has continued to the present, though steadily reducing in size. But the importance of Ontario and Quebec is seen by the fact that 90 percent of imports originated in just those two provinces. The most important commodity was energy, with the state obtaining 61.3 percent of its energy imports from Quebec in the form of hydro-electricity. ${ }^{28}$

In view of the early success of CUSFTA, New York policy makers began to consider what impact further reductions in trade barriers might have. In a study commissioned by the Niagara Mohawk Power Corporation, 36 industries were found to have an absolute advantage over Canada, the largest of which were electrical components and accessories, specialized industrial machinery, railroad equipment, engines and turbines, and industrial machinery. At a more disaggregated level, the study also identified 130 products that individually had great potential as exports. ${ }^{29}$

The inclusion of Mexico in the 1994 agreement was not expected to bring substantial benefits to New York or the Northern Border States. However, both experienced substantial percent increases in trade with Mexico. After five years of NAFTA, the states on the Canadian border increased exports to Mexico by 106 percent ( $\$ 8.1$ billion), while their exports to Canada increased by 13 percent ( $\$ 8.6$ billion).

Over the same period New York exports to Mexico increased by 114 percent ( $\$ 1.13$ billion), while exports to Canada increased by only one percent $\left(\$ .30\right.$ billion) ${ }^{30}$ The fear had been that Canadian companies located in the US might find it advantageous to move to the Southern border, or even to Mexico. The prospect of eliminating tariff

\footnotetext{
${ }^{25}$ Wonnacott described the possibility as a "hub and spoke system" in Canada's Great Free Trade Debate: A Memoir, Ronald J. Wonnacott, CreateSpace Independent Publishing Platform (2016). The reason for Canadian participation was mainly to prevent the US from becoming the only North American hub for industrial production.

${ }^{26}$ Additional concerns for Canada were the decreasing importance of transportation costs and the ongoing shift of manufacturing location in the US from the North to the South since the 1950's (see Duffy, 1994)

${ }^{27}$ The Conference Board of Canada (2007). Tighter Border Security and its Effects on Canadian Exports, Report, June.

${ }^{28}$ Beach (1991). The Canada-United States Economic Relationship: Global and Regional Dimensions, Focus Canada Series, Volume 2. Center for the Study of Canada, Plattsburgh, NY.

${ }^{29}$ Niagara Mohawk Power Corporation (1991). The Export Potential of New York State Under the US-Canada Free Trade Agreement. Sponsored by the New York State Department of Economic Development, unpublished.

30 Davidson (2004). Regional Integration of U.S. Border States with Canada: Evidence from U.S. Exports, in Alan Rugman (Ed.), North American Economic and Financial Integration (pp.69-84). Elsevier B.V, Amsterdam. There is always the debate over whether a percentage or an absolute increase is more significant. Since exports to Mexico had been comparatively small before NAFTA, there resulted relatively large percent increases. 
barriers would presumably open the door for companies to move to Mexico to take advantage of extremely low wages. It was during a series of debates between candidates for President that businessman Ross Perot reinforced this notion when he famously made the prediction that there would be a "giant sucking sound" as companies vacated the US en masse. But for Northern New York, a 1991 study had found that tariffs played a comparatively small role in attracting Canadian investment, so that their reduction should not have any major effects. ${ }^{31}$ This was verified by the fact that by 2008 Clinton County alone had 100 Canadian firms, compared to 28 in 1970 and 56 in 1989. Many of the companies present in the 1970's were still present in 2008, having grown substantially. They maintained close relationships with parent companies in Quebec and tended to specialize in "back-office" operations such as accounting, invoicing, payroll, MIS, and purchasing.

In 2009 personal interviews were conducted on a cross-section of 243 companies located in New York, Vermont, Ohio, and Washington State. It was determined that firms continued to take advantage of the same set of locational benefits found in the 1991 study of Northern New York mentioned above. ${ }^{32}$ The2009 study also made an interesting discovery regarding business attitudes toward various levels of integration. When asked whether a European-style union would be of any interest to them, the results indicated that almost all respondents wanted complete free trade (95 percent), followed by a common market ( 72 percent), more free trade with the Americas (56 percent), and a common currency (53 percent). If an expanded economic integration did take place, almost all respondents (97 percent) said they would expand US operations; none desired to shut down business in Canada. The study also reported that 60 percent were opposed to political integration.

By 2017, bilateral trade in goods between Canada and New York stood at $\$ 41.9$ billion, with Quebec's share $\$ 8$ billion. Two-thirds of total Canadian-American trade passed through six customs stations: Niagara-Niagara, Buffalo-Ft. Erie, Lacolle-Champlain, and Massena-Cornwall in New York; Sarnia-Port Huron and Windsor-Detroit in the state of Michigan. Northern New York's Lacolle-Champlain station, located only 20 miles from Plattsburgh, historically has been the third most important, but was acutely affected by the $9 / 11$ attack in New York City. The border was temporarily closed at that time, but it eventually resulted in significant improvements made to customs procedures in an attempt to increase border security. Companies also began to change their supply-chain strategies from "just in time" to "just in case." Ironically, because of a six-fold increase in the number of customs brokers, the ultimate effect was an even smoother movement of trade goods, or what economists would describe as a "thinning" of the border.

By 2019 there were new forces to contend with, and the question was how Northern New York would fare under newly-elected leaders Donald Trump and Justin Trudeau. Their political differences seemed as pronounced as were Richard Nixon and Pierre Trudeau's in the 1970s. During his campaign for president Mr. Trump spoke repeatedly about scrapping or renegotiating NAFTA, and negotiations began in September of 2017. After several rounds of negotiations, all three NAFTA countries agreed to what has been referred to as a "modernized" NAFTA, renamed the United States-Mexico-Canada Agreement (USMCA). Since NAFTA had already eliminated 98 percent of the tariffs among the member nations, the new agreement focused on regulatory concerns, property rights, enforcement, and various non-tariff barriers, such as quotas. Chief among these were provisions having to do with labor (wage rates), the environment, copyrights, digital trade, and origination of auto parts. The projection was that the USMCA would increase US real GDP by up to $.35 \%$, whereas all previous agreements combined had increased it by only . $2 \% .^{33}$

Northern New York is home to a large aluminum production operation, and it was expected to benefit from the requirement that $70 \%$ of aluminum used in the auto industry must originate in North America.

Such rules also applied to "steel-intensive products," which are likely to apply to two large firms involved in the production of trains and buses (Bombardier and Nova Bus), as well as to many other small manufacturing facilities. In agriculture, the agreement targeted the dairy industry, which has a fairly large presence throughout the region. The various stipulations were expected to mutually expand each country's exports of dairy products to the other country. Both consumers and small businesses (less than 50 employees) were also expected to benefit slightly by an increase in "de minimis" values, i.e. the level at which import tariffs begin to take effect.

${ }^{31}$ Gandhi (1991). The Free Trade Agreement Revisited: Appraisal for New York State. The Canada-U.S. Economic Relationship: Global and Regional Dimensions. Center for the Study of Canada, State University of New York, Plattsburgh, November. Gandhi (1990), The Free Trade Agreement and Canadian Investment in Northern New York. Canadian Journal of Regional Science, 13, p. 205-219.

${ }^{32}$ Gandhi, Glass, and Corporon (2009). Canadian Manufacturing Plant Closing Study, unpublished final report prepared for the Canadian Embassy, Contract 7182433, March 29.

${ }^{33}$ American Council for Capital Formation (2019). NAFTA/USMCA: Past, Present And Future, Center for Policy Research, May. 
Today, Clinton County, located on the border directly between Montreal and New York City, has emerged as an up-and-coming manufacturing-transportation hub. Out of the 150 Canadian companies in Northern New York, 52 are in transportation and aerospace, accounting for over 9,000 jobs. ${ }^{34}$ There have also been significant additions to both the transportation and educational infrastructure. Canadian National Railways purchased existing tracks in the Western part of the region, adding to a rail system that already connected Montreal to New York City and to Western New York State. The resurgence of manufacturing has also spawned new targeted programs in the region's educational system. These include The Center of Excellence in Manufacturing at Clinton Community College, and a Novacab partnership with Clarkson University. It is also not surprising that supply-chain management has become a popular program of study at SUNY-Plattsburgh.

\section{Conclusion}

Trade and investment between Canada and the United States has evolved over the years to the point where the two countries are each other's largest market, and the largest investors in each other's economy. It is now a cliché that the two countries do not produce unique products to sell to each other, but they now co-produce many products for each other; and these often become exports destined for foreign markets abroad. Within this close interaction, the border region of Northern New York has managed to find a niche as a "Southern" suburb of the Montreal metropolis. Unlike many other border areas, it was able to overcome the perception of being just another border wasteland.The initial marketing pitch may have been that Canadian firms could achieve cost savings by avoiding tariffs. But later studies revealed more nuanced reasons for locating in Northern New York, including the desire to be closer to the US market, a reduction of lost time at customs, and the proximity of Canadian parent organizations located in Montreal.

\section{References}

American Council for Capital Formation(2019). NAFTA/USMCA: Past, Present And Future. Center for Policy Research.May.

Beach, R. (1991). The Canada-United States Economic Relationship: Global and Regional Dimensions. Focus Canada Series, Center for the Study of Canada, Plattsburgh, NY, Vol. 2.

Brecher, I. (1965). Capital Flows Between Canada and the United States. Montreal: Private Planning Association of Canada, p. 5.

Caves, R. (1967). Trade and Economic Structure: Models and Methods, Cambridge: Harvard University Press.

Chapman, C. (2020). Officials Praise Signing of USMCA.Plattsburgh Press-Republican, January 30, p. A1.

Csipak, J. (1992). Retailing South of the Border: the Case of Quebec Shoppers in Plattsburgh, New York. The Canada-US Economic Relationship.Focus Canada Series, Center for the Study of Canada, Plattsburgh, NY.

The Conference Board of Canada (2007). Tighter Border Security and its Effects on Canadian Exports, June.

Davidson, L. (2004). Regional Integration of U.S. Border States with Canada: Evidence from U.S. Exports, in Alan Rugman (Ed.), North American Economic and Financial Integration. Elsevier B.V.: Amsterdam, 69-84.

Dominion Bureau of Statistics (1967). The Canadian Balance of International Payments and International Investment Position, 1963, 1964, 1965. Ottawa: Queens Printers.

Duffy, N. (1994). The Determinants of State Manufacturing Growth Rates: A Two-Digit-Level Analysis. Journal of Regional Science, 34 (2), 137-162.

Gandhi, P. (1991). The Free Trade Agreement Revisited: Appraisal for New York State. The Canada-U.S. Economic Relationship: Global and Regional Dimensions. Center for the Study of Canada, State University of New York, Plattsburgh, November.

(1990). The Free Trade Agreement and Canadian Investment in Northern New York. Canadian Journal of Regional Science, 13, 205-219.

. (1971). Canadian Investment in Clinton County: Some Empirical Observations on Location. Papers on the Social Sciences, State University of New York at Plattsburgh, 4, 33-44.

Harris, S. (1957). International and Interregional Economics, New York: McGraw- Hill Book Co. Inc.

Hoover, E. M. (1963). The Location of Economic Activity, New York: McGraw-Hill Book company, Inc.,p. 222.

Isard, W. (1956). Location and Space Economy, Cambridge: The MIT Press.

McGahey, R. M. and Doh, J. P. (1991). Effects of Freer Trade on New York State: Economic Impact and Policy Considerations.In Economic Opportunities in Freer U.S. Trade with Canada, Menz, F. C. and Stevens, S.

A. (eds.), Chapter 8, State University of New York Press, Albany, NY.

New York State Department of Commerce (1965). Business in New York State, An Interview. Canada Businessmen

Tell Why They Established a Branch Plant in New York State.Albany, NY, November-December.

Royal Commission on Canada's Economic Prospects (1957).Final Report (1957).Ottawa, November, p. 48.

\footnotetext{
${ }^{34}$ Chapman, Cara (2020). Officials Praise Signing of USMCA. Plattsburgh Press-Republican, January 31, p. A1.
} 
Rugman, A. M. (1987). Outward Bound: Canadian Direct Investment in the United States. Toronto: C.D. Howe Institute.

Statistics Canada (2018). International Investment Position, Canadian Direct Investment Abroad and Foreign Direct Investment in Canada, by Country.

Tupper, S.R. and Bailey, D.L. (1967). Canada and the United States: the Second Hundred Years. New York: Hawthorn Books, Inc., p. 99.

Wonnacott, R. J. (2016). Canada's Great Free Trade Debate: A Memoir. CreateSpace Independent Publishing Platform.

Wonnacott, R. J. and Wonnacott, P. (1967). Free Trade Between the United States and Canada. Harvard University Press, Cambridge, Massachusetts.

Young, J. H. (1957). Canadian Commercial Policy. Ottawa: Royal Commission on Canada's Economic Prospects. 